\title{
Association of disease activity and pericardial effusion on systemic lupus erythematosus patients
}

\author{
Nurhay Abdurahman, Idrus Alwi, Lukman Hakim, Dasnan Ismail, Hardjanti Soelistijo*
}

\begin{abstract}
Abstrak
Efusi perikard merupakan kelainan jantung yang paling sering ditemukan pada pasien lupus eritomatosus sistemik. Adanya efusi perikard sering dikaitkan dengan aktivitas penyakit, hipoalbuminemia dan gagal ginjal kronik. Telah dilakukan penelitian prospektif untuk melihat hubungan antara aktivitas penyakit dengan kejadian efusi perikard pada pasien rawat inap dan rawat jalan di Bagian Penyakit Dalam RS. Dr. Cipto Mangunkusumo mulai bulan Oktober 1995 sampai Juli 1996. Aktivitas penyakit dinilai dengan Lupus Activity Criteria Count (LACC). Dilakukan pemeriksaan ekokardiografi mode-M dan 2-D untuk mendeteksi efusi perikard pada tiga puluh enam pasien LES masing-masing 17 pasien LES aktifdan 29 LES tak aktif. Pada penelitian ini efusi perikard lebih sering ditemukan secara bermakna pada LES aktif $(p<0.01)$ dan merupakan faktor risiko yang independen.
\end{abstract}

\begin{abstract}
Prericardial effusion (PE) is the most common cardiac abnormality found in SLE. The presence of PE was frequently associated with disease activity, hypoalbuminemia and chronic renal failure. A prospective study had been done to observe the correlation between disease activity, and the presence of PE in patients with SLE admitted at the Department of Internal Medicine Dr. Cipto Mangunkusumo Hospital from October 1995 to June 1996. In this study the disease activity was measured with lupus activity criteria count (LACC) and $M$-mode and 2-D echocardiography to detect the presence of pericardial effusion. Of the 36 patients with SLE, 17 patients were found with active SLE and 19 with inactive SLE. This study showed that the PE was more frequently found in active $S L E(P<0.01)$ and constituted independent risk factors.
\end{abstract}

Keywords : Systemic lupus erythematosus, pericardial effusion, disease activity

\section{INTRODUCTION}

Systemic lupus erythematosus (SLE) is an autoimmune disease with highly varied clinical manifestations involving many organs. ${ }^{1-3}$ Cardiac abnormalities constitute one of very important SLE clinical manifestations, because of their impact on morbidity and mortality. ${ }^{2,4,5}$

Pericarditis is the most frequently encountered cardiac abnormality in SLE. ${ }^{6-11}$ Doherty and Siegel, ${ }^{6}$ in their review article reported a prevalence of pericarditis amounting 25,6\% out of 1194 SLE patients, and from 254 autopsy cases, they found an even higher prevalence of $62,1 \%$.

Division of Cardiology, Department of Internal Medicine University of Indonesia, Faculty of Medicine/Dr. Cipto Mangunkusumo Hospital, Jakarta, Indonesia

* Division of Allergy and Immunology Department of Internal Medicine, University of Indonesia, Faculty of Medicinef Dr. Cipto Mangunkusumo Hospital, Jakarta, Indonesia
These figures demonstrate that asymptomatic pericardial involvement is often found. Cohen and $\mathrm{Li}_{2}{ }^{4}$ reported a mortalities due to pericarditis and myocarditis in $15 \%$ of their SLE patients. With increasing SLE patient life expectancy and better imaging modalities, cardiac involvement in SLE may be more frequently diagnosed. ${ }^{5,6}$ Using M-mode and 2-D echocardiography, the prevalence of pericardial effusion in SLE patients was reported to range from 20 to $54 \%^{7,12-19}$ in which most of them were without clinical manifestations. ${ }^{8,12,16}$

Lupus pericarditis may be manifested as cardiac tamponade cases. ${ }^{20-26} \mathrm{Kahl}^{27}$ reported cardiac tamponade in $13 \%$ of pericarditis cases and in 2,5\% of all SLE cases. Several factors might contribute to the development of cardiac abnormalities in SLE, ie: disease activity, ${ }^{12,14,16}$ duration of disease, ${ }^{6,28-30}$ length of steroid use $\mathrm{s}^{31}$ and the presence of anticardiolipin antibody. ${ }^{15,28,32-36}$ Some studies indicated that there was a relationship between disease activity and cardiac abnormalities in SLE. ${ }^{13,37,38}$ However the association 
of disease activity and pericardial effusion is still unknown due to the fact that, bias caused by confounding factors like hypoalbuminemia and chronic renal failure were not considered. In addition the criteria of disease activity used are also varied. This study was therefore performed to assess association of disease activity and pericardial effusion prevalence by taking into account also all possible confounding factors.

\section{MATERIALS AND METHODS}

A cross sectional study was conducted on all hospitalized and ambulatory SLE patients in the Department of Internal Medicine, University of Indonesia Medical School, Dr. Cipto Mangunkusumo Hospital, Jakarta from October 1995 to July 1996 . The diagnosis of SLE was established according to the revised ARA criteria. ${ }^{39}$ Exclusion criteria were as follows (1) pericardial effusion as the only clinical manifestation of SLE activity, (2) pulmonary or extrapulmonary tuberculosis, (3) MCTD (mixed connective tissue disease), (4) acute myocardial infraction, (5) congestive heart failure, (6) malignancy, (7) acute rheumatic fever, (8) postpericardiectomy, (9) postirradiation of the chest. Disease activity was assessed by using LACC (Lupus Activity Criteria Count). ${ }^{40}$ Based on calculation the minimal number of sample was 10 patients for pericardial effusion (PE) and non pericardial effusion (NPE) groups.

For all patients, a complete history and physical examination, standard ECG and chest X ray were taken. Laboratory investigatios included: peripheral blood and urinalysis, ureum, creatinin, albumin, antidsDNA, complement C3 and C4. M-mode and twodimensional echocardiographic examinations were conducted in all patients by using a Toshiba echocardiographic unit with mechanical transducer of 3,5 MHZ. Standard parasternal long axis, short axis and apical 4 chamber examination were done. Recordings were performed with Toshiba ultrasonostrip chart on paper speed of $50 \mathrm{~mm} / \mathrm{second}$. Echocardiographic date were read by a cardiologist who did not know the patients condition and the results were analyzed according to the recommendation of the American Society of Echocardiography. ${ }^{41}$

\section{RESULTS}

In a period from October 1995 to July 1996, 42 SLE patients satisfied the 1982 ARA criteria. Four patients were excluded from the study because they did not appear for echocardiographic examination and two other patients with MCTD were also excluded, leaving 36 eligible patients.

\section{Prevalence of pericardial effusion}

Based on echocardiographic examination $13(36.11 \%)$ SLE patients were shown to have pericardial effusion and $23(63.89 \%)$ patients had no pericardial effusion. Of the 13 patients with pericardial effusion, 10 (76.92\%) patients had mild effusion, 2 (15.38\%) patiens had moderate effusion and $1(7.69 \%)$ patient had severe effusion.

Seventeen patients $(47.2 \%)$ had active SLE according to ALCC criteria, of whom 11 patients $(64.7 \%)$ had pericardial effusion. Of the remaining inactive patients only 2 subjects $(10.5 \%)$ had pericardial effusion.

\section{Characteristics of patient}

Patient characteristics of both groups of patients are listed in Table 1.

\section{Association of disease activity and prevalence of pericardial effusion}

In the PE group 11 patients (83.3\%) had active SLE, whereas in the NPE group active SLE was found in 6 patients $(26.09 \%)(\mathrm{X} 2=9.1 \mathrm{p}=0.002$, OR 15$)$. To assess the relationship of some risk factors such as disease activity, chronic renal failure, severe hypoalbuminemia and the presence of pericardial effusion, multivariate analysis was done with Backward stepwise method (LR). Prevalence of pericardial effusion was mostly related to disease activity $(\mathrm{p}=0.002$ $\mathrm{Cl}=2.65-91.56$ ).

\section{DISCUSSION}

The prevalence of pericardial effusion in our series of 36 patients, was $36.11 \%$. This figure was similar to a prevalence of $21-54 \%$ reported in the literature. Table 2 shows the prevalence of pericardial effusion in various reports.

The apparently slight disparity in the prevalence of pericardial effusion could be due to differences in the level of disease activity at the time of echocardiographic examination and in racial distribution. Pericardial effusion was mild in $27.78 \%$, of the patients moderate in $5.56 \%$ and severe in $2.78 \%$. These figures are not so different from another study by Badui et $\mathrm{al}^{18}$ who found, moderate and severe pericardial effusion in $26 \%, 9 \%$ and $4 \%$, of their patients respectively. Cervera et al ${ }^{12}$ also came up with similar figures, i.e. mild, moderate, and severe pericardial 
Table 1. Patient clinical characteristics of PE and NPE groups

\begin{tabular}{|c|c|c|c|c|}
\hline & & $\mathrm{PE}$ & NPE & $\mathrm{p}$ \\
\hline Sex & $(\mathrm{M} / \mathrm{F})$ & $11 / 223 / 0 \quad 0.1238$ & & \\
\hline Age & (years) & $29.15(\mathrm{SD}=7.82)$ & $27.87(\mathrm{SD}=8.32)$ & 0.652 \\
\hline Duration of disease & (months) & $14.58(\mathrm{SD}=21.72)$ & $27.65(\mathrm{SD}=19.10)$ & 0.069 \\
\hline Duration of therapy & (months) & $14.04(\mathrm{SD}=22.02)$ & $27.51(\mathrm{SD}=19.26)$ & 0.064 \\
\hline Dose of prednison therapy & $(\mathrm{mg})$ & $20.00(\mathrm{SD}=24.24)$ & $20.22(\mathrm{SD}=21.02)$ & 0.978 \\
\hline \multicolumn{5}{|l|}{ Blood pressure } \\
\hline systolic & $(\mathrm{mmHg})$ & $132.69(\mathrm{SD}=24.03)$ & $115.65(\mathrm{SD}=15.32)$ & 0.014 \\
\hline diastolic & $(\mathrm{mmHg})$ & $89.23(\mathrm{SD}=15.53)$ & $75.22(\mathrm{SD}=10.39)$ & 0.003 \\
\hline Haemoglobin & $(\mathrm{g} / \mathrm{dl})$ & $9.03(\mathrm{SD}=2.21)$ & $12.12(\mathrm{SD}=1.62)$ & 0.0001 \\
\hline Albumin & $(\mathrm{g} / \mathrm{dl})$ & $2.89(\mathrm{SD}=1.01)$ & $4.32(\mathrm{SD}=0.78)$ & 0.0001 \\
\hline Albumin $<2.5 \mathrm{mg} / \mathrm{dl}$ & (case/n) & $6 / 13$ & $1 / 23$ & 0.005 \\
\hline Urea & $(\mathrm{mg} / \mathrm{dl})$ & $89.77(\mathrm{SD}=81.63)$ & $26.13(\mathrm{SD}=13.80)$ & 0.001 \\
\hline Creatinin & $(\mathrm{mg} / \mathrm{dl})$ & $3.19(\mathrm{SD}=4.97)$ & $0.82(\mathrm{SD}=0.59)$ & 0.029 \\
\hline CRF & (case/n) & $5 / 13$ & 0 & 0.003 \\
\hline Proteinuria $(0.5 \mathrm{~g} / \mathrm{dl})$ & (case/n) & $8 / 13$ & $2 / 23$ & 0.007 \\
\hline
\end{tabular}

effusion in $20 \%, 4 \%$ and $3 \%$, of the patients respectively. Difference in the level of disease activity SLE at the time of examination could explain the dissimilar distribution of the severity pericardial effusion in some reports. The higher prevalence of pericardial effusion in active SLE in our study compared to that in the inactive SLE patients was in accordance with other reports by Cervera et al ${ }^{12}$ and Leung et al. ${ }^{16}$

\section{Association of disease activity and prevalence of pericardial effusion}

In this study disease activity was a risk factor for pericardial effusion with an odds ratio of 15 times compared to inactive group. This is in agreement with some studies done abroad. Crozier et $\mathrm{al}^{14}$ reported from their series of 50 SLE patients a trend towards higher prevalence of pericardial effusion in active SLE as determined by LACC criteria. A possible explanation is the presence of confounding factors such as hypoalbuminemia, chronic renal failure, difference in the level of disease activity.

Cervera et $\mathrm{al}^{12}$ reported pericardial effusion only in active SLE patient. Activity criteria were if there is symptom or the following signs: specific dermatitis (malar rash), arthritis, serositis, central nervous system disorder (recently occured chorea, convulsion, psychosis, organic brain syndrome not caused by drug or metabolic disorder, cerebrovascular disturbance due

Table 2. Prevalence of Pericardial Effusion in SLE

\begin{tabular}{|c|c|c|c|c|c|}
\hline Researchers & Year & $\begin{array}{l}\text { Number } \\
\text { of patient }\end{array}$ & $\begin{array}{l}\text { Modalities Pericardial } \\
\text { Effusion }\end{array}$ & $\mathrm{n}$ & $\%$ \\
\hline Authors & 1996 & 36 & M-mode, 2-D & 13 & 36.11 \\
\hline Ito et al ${ }^{19}$ & 1979 & 48 & M-mode & 22 & 45.80 \\
\hline Chia et al (quoted from 6) & 1981 & 21 & M-mode & 5 & 24.00 \\
\hline Badui et al ${ }^{18}$ & 1985 & 100 & M-mode & 39 & 39.00 \\
\hline Klinkoff et al ${ }^{17}$ & 1985 & 47 & M-mode, 2-D & 10 & 21.00 \\
\hline Doherty et $\mathrm{al}^{8}$ & 1988 & 50 & M-mode, 2-D & 21 & 42.00 \\
\hline Leung et $\mathrm{al}^{16}$ & 1990 & 75 & M-mode, 2-D & 21 & 28.00 \\
\hline Nihoyannopoulos ${ }^{15}$ & 1990 & 93 & M-mode, 2-D & 19 & 20.43 \\
\hline Crozier et al ${ }^{14}$ & 1990 & 50 & M-mode, 2-D & 27 & 54.00 \\
\hline Ong et al ${ }^{13}$ & 1992 & 40 & M-mode, 2-D & 19 & 47.50 \\
\hline Cervera $^{12}$ & 1992 & 70 & M-mode, 2-D & 19 & 27.00 \\
\hline
\end{tabular}


to embolism, thrombocytopenia $(<100.000 / 1)$, haemolytic anaemia, vasculitis (biopsy), or nephritis (recently occured haematuria $>10$ erythrocyte/field, or cylinder, or proteinuria ( $>500 \mathrm{mg} / 24$ hour) or increase in serum creatinin of $25 \%$.

Leung et al ${ }^{16}$ also observed pericardial effusion more commonly in active SLE patients. Criteria of activity were when there is at least 3 of the following clinical features: fever, without evidence of infection, serositis, new skin lesion or exacerbation, recently occured or progressive alopecia, oral ulcers, central nervous system involvement, lymphadenopathy, leucopenia, thrombocytopenia, ESR $>55 \mathrm{~mm} /$ hour without evidence of infection, low complement and active nephritis.

Although Cervera et al ${ }^{21}$ and Leung et al, ${ }^{16}$ used different criteria for activity their components were not still very much alike. Macedo et al, ${ }^{42}$ found prevalence of pericardial effusion was associated with higher SLEDAI score disease activity. SLEDAI score include components which are very similar to LACC, but each component is measured for its score.

Based on above mentioned studies, one may conclude that pericardial effusion occurs more frequently in active SLE patients. This is in line with the pathogenesis of pericardial effusion in SLE that is assumed to be due to immune complex deposit originating from antigen and antibody reaction. In active SLE the increasing formation of antibody will elevate circulating immune complex which inturn will facilitate tissue deposit.

Ong et $\mathrm{al}^{13}$ however did not find any relationship between LACC disease activity and cardiac abnormalities in SLE including: valvuvar deformity, left ventricular disorder, pericardial abnormalities (pericardial effusion and pericardial thickening) and right cardiac disorder. In this study, however, the association between pericardial effusion and disease activity was not specifically evaluated.

In SLE, pericardial effusion may also be caused by hypoalbuminemia and chronic renal failure. In a report by Ong et $\mathrm{al}^{13}$ of hypoalbuminemia (serum albumin < $3,5 \mathrm{~g} / \mathrm{dl}$ ) was found in $76 \%$ of patients with pericardial effusion, and all of them had moderate and secere pericardial effusion. Nevertheless they failed to consider hypoalbumemia as a contributing factor of pericardial effusion. In our study hypoalbunemia (albumin $<3,5 \mathrm{~g} / \mathrm{dl}$ ) was detected in $10(76.92 \%)$ patients with pericardial effusion. In the PE group normal al- bumin level (albumin $>4 \mathrm{~g} / \mathrm{dl}$ ) was found in one patient with pericardial effusion and one patient with mild pericardial effusion. One other patient with an albumin concentration of $3,5 \mathrm{~g} / \mathrm{dl}$ had mild pericardial effusion. In NPE group albumin level was normal in most cases (91.3\%).

The occurence of generalized edema was associated to severe hypoalbunemia $(<2,5 \mathrm{~g} / \mathrm{dl})$ including pericardial effusion. Based on absolute Fisher tests this severe hypoalbunemia was significantly more prevalent in the PE group compared to NPE group $\left(X^{2}=6.79\right.$ $\mathrm{p}=0.005$ ).

Chronic renal failure in another potential cause of pericardial effusion (uremic pericarditis), especially in overload condition. In the PE group, chronic renal failure was found in 5 out of 13 patients (38.46\%) with pericardial effusion, while in the NPE group chronic renal failure was not observed. Of these five patients, one patient suffered from pericardial effusion and four cases had mild pericardial effusion. On absolute Fisher tests, chronic renal failure was found significantly more common in the PE group compared to the NPE group $\left(\mathrm{X}^{2}=7.309 \mathrm{p}=0.003\right)$.

At multivariate analysis, of various risk factors: disease activity, hypoalbunemia and chronic renal failure, disease activity was found to be an independent risk factor $(p=0.002)$. The assocation of hypoalbunemia and chronic renal failure with pericardial effusion was not significant.

\section{REFERENCES}

I. Boumpas DT, Austin III GA, Fessler BJ, et al. Systemic lupus erythematosus: emerging concepts. Part I: renal, neurophychiatric, cardiovascular, pulmonary, and hematologic disease. Ann Intern Med 1995;122:940-50.

2. Quismorio Jr FP. Cardiac abnormalities in systemic lupus erythematosus. In: Wallace DJ, Hahn BH, eds. Dubois' Lupus Erythematosus. 4th ed. Philadelphia: Lea \& Febiger 1993:332-42.

3. Stevens NM. Systemic lupus erythematosus and the cardiovascular system: the heart. In: Lahita RG (ed). Systemic Lupus Erythematosus. 2th ed. New York: Churchill Livingstone; 1992:707- 17.

4. Cohen MG, Lie EK. Mortality in systemic lupus erythematosus: active disease is the most important factor. Aust NZ J med 1992;22:5-8.

5. Ward MM, Pyun E, Studensky S. Cuases of death in systemic lupus erythematosus. Arthritis Rheum 1995;38:1492-9.

6. Doherty NE, Siegel RJ. Cardiovascular manifestations of systemic lupus erythematosus. Am Heart J;1985:1257-65.

7. Mandell BF. Cardiovascular involvement in systemic lupus erytematosus. Scan Arthritis Rheum 1987;17:126-41. 
8. Doherty NE, Feldman G, Maurer G, Siegel RJ. Echocardiographic findings in systemic tupus erythematosus. Am J Cardiol 1988;61- 1144

9. Ansari A, Larson PH, Bates HD. Cardiovascular manifestations of systemic tupus erythematosus. Prog Cardiovasc Dis 1985;274:21-34.

10. Jouhikainen T, Pohjola SS, Stephansson E. Lupus anticoagulant and cardiac manifestations in systemic lupus erythematosus. Lupus 1994;13(3):167-7.

11. Maniscolco BS, Felnes JM, McCans JL, Chiopella JA. Echocardiographic abnormalities in systemic lupus erythematosus. Circulation 1975;15:Suppl II-211.

12. Cervera R, Font J, Pare C, et al. Cardiac disease in systemic lupus erythematosus: prospective study of 70 patients. Ann Rheum Dis 1992;51:156-9.

13. Ong ML, Veerapen K, Chambers JB, Lim MN, Mainsavagar M, Wang F. Cardiac abnormalities in systemic lupus erythematosus: prevalence and relationship to disease activity. Int J Cardiol 1992;34:69- 74.

14. Crozier IG, Li E, Milne MH, Nicholls MG. Cardiac involvement in systemic tupus erythematosus detected by echocardiogcaphy. Am J Cardiol 1990;65:1 145-8.

15. Nihoyannopoulos P, Gomez PM, Joshi J, Loizou S, Walport MJ, Oakley CM. Cardiac abnormalitis in systemic lupus erythematosus. Circulation 1990;81:369-75.

16. Leung WH, Wong KL, Lau CP, Wong CK, Cheng $\mathrm{CH}$. Cardiac abnormalities in systemic lupus erythematosus: a procpective M- mode, cross sectional and Doppler echocardiographic study. Int J Cardiol 1990;27:267-75.

17. Klinkhoff AV, Thompson CR, Reid GD, Tomlinson CW. $M$-mode and two dimensional echocardiographic abnormalities in systemic lupus erythematosus. JAMA 1985;253:3273-7.

18. Badui E, Garcia-Rubi D, Robles E. Cardiovascular manifestations in systemic lupus crythematosus. Prospective study of 100 patients. Prog Cardiovasc Dis 1985;27:421-34.

19. Ito M, Kagiyama Y, Omura I, et al. Cardiovascular manifestations in systemic lupus erythematosus. Japan Circ J 1979;143:985-94

20. Gulati S, Kumar L. Crdiac tamponade as an initial manifestation of systemic tupus erythematosus in early childhood. Ann Rheum Dis;51:279-80.

21. Ehrenfeld M, Asman A, Sphilberg O, Samra Y. Cardiac tamponade as the presenting manifestation of systemic lupus erythematosus. Am J Med 1989;86:626-7.

22. Leung WH, Lau CP, Wong CK, Leung CY. Fatal cardiac tamponade in systemic lupus erythematosus - a hazard of anticoagulation. Am Heart J 1990;119:422-3.

23. Reiner JS, Fuirie RA. Cardiac tamponade as an initial manifestation of systemic tupus erythematosus. J Rheumatol $1989 ; 16: 1127-9$

24. Zashin SJ, Lipsky PE. Pericardial tamponande complicating systemic lupus erythematosus. J Rheumatol 1989;16:374-7.

25. Omdal R, Dickstein K, Brandis CV. Cardiac tamponade in systemic lupus erythematosus. Scand J Rheumatol 1988; 17:55-7.

26. Averbuch M, Bojko A, Levo Y. Cardiac tamponade in the early postparum period as the presenting and predominant manifestation of systemic lupus erythematosus. J Rheumatol $1986 ; 13: 44$.
27. Kahl LE. The spectrum of pericardial tamponade in systemic lupus erythematosus. Report of ten patients. Arthritis Rheum 1992;35:1343-9.

28. Gaive E, Candei-Riera S, Pigrau C, et al. Prevalence, morphologic types, and evolution of cardiac valvular disease in systemic lupus erythematosus. N Engl J Med 1988;319:81723.

29. Bahl VK, Vasan RS, Aradhye, Malavia AN. Prevalence of cardiac abnormalities early in the course of systemic lupus erythematosus. Am J Cardiol 1991;68:1540-1.

30. Enomoto K, Kaji Y, Mayumi, et al. Frequency of valvular regurgitation by color Doppler echocardiography in systemic lupus erythematosus. Am J Cardiol 1991;67:209-11.

31. Bulkley BR, Roberts WC. The heart in systemic lupus erythematosus and the changes induced by corticosteroid therapy. Am J Med 1975;158:243-64.

32. Roldan CA, Shively BK, Lau CC, Gurule FT, Smith EA, Crawford MH. Systemic lupus erythematosus valve disease by transesophageal echocardiography and the role of antiphospholipid antibodies. J Am Coll Cardiol 1992;20:112734.

33. Gleason CB, Stoddard MF, Wagner SG, Longaker RA, Pierangeli, Harris EN. A comparison of cardiac valvular involvement in the primary antiphospholipid syndrome versus anticardiolipin negative systemic erythematosus. Am Heart J 1993;125:1123-9.

34. Khamashta MA, Cervera R, Asherson RA, et al. Association of antibodies against phospholipid with heart valve disease in systemic lupus erythematosus. Lancet 1990;335:1541-4.

35. Leung WH, Wong KL, Lau CP, Wong CK, Liu BW. Association between antiphospholipid antibodies and cardiac abnormalities in patients with systemic lupus erythematosus. Am J Med 1990;89:411-9.

36. Chartash EK, Lans DM, Paget SA, Qamar T, Lockshin MD. Aortic insufficiency and mitral regurgitation in systemic lupus erythematosus and the antiphospholipid syndrome. Am J Med 1989;86:407-12.

37. Lolli C, Foscoli M, Giofre R, Tarquinii M, Pasquali S, Toschi GP. Cardiac anomalie in systemic lupus erythematosus: their prevalence and relation to duration, disease activity and the presence of antiphospholipid antibodies. G Ital Cardiol 1993;23:1125-34.

38. Cujec B, Sibley J, Haga M. Cardiac abnormalities in patients with systemic lupus erytematosus. Can J Cardiol 1991;7:343-9.

39. Tan EM, Cohen AS, Fries JF, et al. The 1982 revised criteria for the classification of systemic lupus erythematosus. Arthritis Rheum 1982;25:1271-7.

40. Urowitz MB, Gladman DD, Tozman ECS, Goldsmith CH. The lupus activity criteria count (LACC). J Rheumatol 1984;11:783-7.

41. Shan DJ, Demaria A, Kissio J, Weyman A. The committee on M-mode standardization of the American Society of Echocardiography. Recommendation regarding quantitation M-mode echocardiography: result of a survey of echocardiography measurements. Circulation 1978;58:1072-83.

42. Macedo TB, Margaredo MS, Rassi C, et al. Cardiac abnormalities in SLE. Abstracts. Lupus Avis Intem J Jerusalem, 26-31 March 1995. 